V. Plaskalnyi, postgraduate student

Taras Shevchenko National University of Kyiv, Kyiv, Ukraine

\title{
KEY COMPONENTS OF THE UNIVERSAL PROCEDURE OF ANTHROPIZATION EXTENT' ANALYSIS FOR AGGREGATION WITHIN THE TERRITORY OF UKRAINE
}

Four European and national conceptions for identification of landscapes' anthropization extent were considered and differentiated. The mentioned conceptions are conceptions of archiretrospective (naturalness), sozological-idealized (wilderness), actual-potential (hemeroby) and geoecological-naturemanagement analysis.

Landscape anthropization is a process of their transformation through anthropogenic impact with specific intensity and consequences of this process, as a result it can be identified existence geosystems with different anthropization level. Alongside, conceptual bases and procedure of anthropization extent' analysis for Ukrainian landscapes were covered. The procedure is interoperable for all-European and Ukrainian approaches and consists of four components: common-matter, parametric, logic-mathematical and verification implementation component. It embodies scheme and scales of landscapes' anthropization extent depending on anthropogenic impact' extent of land use and land cover systems. This impact is specified by corresponding degrees of hemeroby, impact intensity, geoecological favourableness and naturalness of indicated systems. The scale of geoecological situation in land use was also developed. Means were defined for verification and implementation of the procedure concerning landscape aggregations within the territory of Ukraine. Up-to-date and potential geoinformation basis, including GIS technology, satellite imageries, and geospatial web services, was investigated for examination of land covers and land use systems, for cartographic visualization and quantitative data obtaining of the landscape anthropization extent. The possibility of the practical verification and application of this procedure for landscape aggregations within the territory of Ukraine was revealed to determine the state and resilience of geosystems to anthropogenic pressure. Newly represented interoperable procedure will give opportunity to make more rational management decisions in evaluating potential and existing geoecological risks, in defining impact limits, permissible pressure on landscape or natural complexes. This is necessary to ensure sustainable environmental management, territory rational organization, optimal landscape planning and monitoring of anthropogenic activity.

Keywords: anthropization, anthropogenic transformation, landscapes, hemeroby, land use, land cover, cartographic services, satellite data.

http://doi.org/10.17721/1728-2721.2016.64.13

УДК 911.3

Л.Ковалевич, асп. Київський національний університет імені Тараса Шевченка, Київ

\section{ПОЛІТИКА ДЕРЖАВ ЄВРОПЕЙСЬКОГО СОЮЗУ 3 ПРОТИДІЇ СЕЦЕСІОНІЗМУ}

В статті розелянуто роль внутрішньої політики держави у вирішенні міжрегіональних протиріч та протидії сецесійним процесам. Висвітлено основі способи реагування уряду на посилення відцентрових тенденцій в окремих регіонах. Проаналізовано головні характерні риси державної політики країн Європейського Союзу, в яких наявні регіони з високим потенціалом сецесійного конфлікту. Підкреслено необхідність виваженої внутрішньої політики уряду для запобігання ескалації внутрішньодержавних протиріч. Досліджено вплив форми державного устрою на мінімізацію міжрегіональних протиріч. Розглянуто приклади успішного вирішення регіональних конфліктів окремими європейськими державами.

Ключові слова: сецесіонізм, Євросоюз, державна політика, сецесійні рухи, міжрегіональні конфлікти.

Вступ. Постановка проблеми. В сучасну епоху повсюдної тотальної взаємозалежності, яка відбувається у світі політичних процесів, проблеми, пов'язані з наявністю в окремих регіонах планети осередків сецесіонізму, зумовлюють глобальне посилення політичної та економічної напруженості. Важливою рисою, на якій слід підкреслити, $€$ те, що сецесіонізм в різних регіонах світу проявляється по-різному: в різних формах, із різними засобами, методами боротьби та цілями, починаючи від простих заяв та погроз і закінчуючи збройною боротьбою та тероризмом. У світлі глобалізаційних процесів певна подія в одному кінці світу може стати прецедентом для будь-якої іншої. А розвиток подій на будь-якій території зі змішаним населенням може піти або шляхом мирного співіснування і політичної стабільності, або прямувати до жорстоких конфліктів. Значною мірою це залежить від внутрішньої етнічної політики уряду. Оскільки проблема врегулювання сецесіонізму в Україні стоїть на порядку денному, то особливої актуальності набуває дослідження та аналіз успішного досвіду вирішення міжрегіональних протиріч в інших державах, зокрема в країнах Європейського Союзу.

Аналіз останніх досліджень і публікацій. Вагомий вклад у вивчення регіональних аспектів сецесійних процесів та особливостей державної політики їх регулювання як загалом, так і в окремих країнах внесли А. Баранов, Н. Беліцер, Б. Коппітерс, М. Емерсон, М. Хейссен, А. Зоткін, В Лажнік, Н. Фонсека та ін.

Метою статті $€$ висвітлення основних способів реагування центральних органів держав на сецесійні процеси всередині країни та виділення основних дій, здійснених країнами, що входять до складу Євросоюзу та в межах яких діють активні сецесійні рухи, задля їх врегулювання.
Виклад основного матеріалу. Сепаратизм і його крайня форма - сецесіонізм (як політика і практика суспільно-політичного руху, що спрямовані на здобуття державного суверенітету окремою етносоціальною спільнотою на території ії̈ проживання в межах існуючої держави) - явище, яке потенційно присутнє у будь-якій поліетнічній державі. Посилення чи ослаблення центральної влади, вплив різноманітних факторів, пов'язаних 3 політичними та соціокультурними перетвореннями в суспільстві сприяють активізації сецесійних процесів.

Коли і чи взагалі виникне сецесійний рух залежить в основному від внутрішньої політики, відносин між групами і регіонами всередині країни. Виникнення сецесійного руху можливе за наявності двох умов: по-перше, дискримінації етнічної меншості з боку державної влади, а по-друге, активна національна політична протоеліта, яка б очолювала цей рух. Та чи досягне сецесійний рух своїх цілей залежить від міжнародної політики, балансу інтересів і сил на зовнішній арені. Іноді, розгляд засобів для підтримки руху, включаючи зовнішню допомогу, може значно модифікувати сецесійні почуття (зменшити чи збільшити) [4]. Сецесія лежить прямо на стику внутрішньої та зовнішньої політики, проте в більшості випадків поява сепаратизму може бути пояснена внутрішньою етнічною політикою.

Загалом сецесійний рух як прагнення певних регіонів країни до відділення, набуття суверенітету є частково проявом захисної реакції на ті процеси, які не влаштовують частину суспільства в переломні періоди його розвитку. Загалом, принцип самовизначення народів передбачає різні способи політико-територіальної організації спільності у внутрішньодержавних відносинах: створення суб'єкта фредерації, організацію місцевого самоврядування, екстериторіальні форми національно-

(С) Ковалевич Л., 2016 
культурної автономії і т. п. I тільки вищу форму самовизначення становить право утворити державу. Якщо все ж територіальне співтовариство наполягає на сецесії, повинні дотримуватися чіткі правові умови: конституційні норми про право сецесії, закони про порядок виходу зі складу держави. У них повинні визначатися гарантії та механізми захисту громадян, автономних територій, суб'єктів федерації і всієї держави, а також встановлюватися перехідний період, під час якого вирішуються всі питання захисту прав та інтересів сторін. Згідно $з$ міжнародним правом, рішення про відділення приймається на референдумі в умовах миру і демократії, забезпечуваних легітимними владою [1]. Самовизначення має відбуватися тільки на основі повної рівноправності всіх громадян, пріоритету прав людини без переваг для корінних (титульних) етносів, без найменшої дискримінації населення другий етнічності. На практиці сецесія в більшості випадків руйнівна й збиткова, тягне за собою масові порушення прав людини. До сецесії можна вдаватися тільки на конституційних підставах і лише в тому випадку, якщо всі інші способи вирішення протиріч вичерпані. Ще одним способом вирішення регіональних конфліктів $€$ створення "багатонаціональні фредерації" - такої моделі державного устрою, при якій національні меншини об'єднуються у державі на федеративних началах через якусь фрорму територіальної автономії, і в яких проведені внутрішні кордони і розподілені повноваження таким чином, щоб забезпечити кожній групі можливість зберегти себе як окреме соціокультурне утворення. Багатонаціональні фредерації можуть не тільки вирішувати мирним і демократичним шляхом конфолікти, викликані конкуруючими у них ідентичностями, а також забезпечувати високий рівень життя й індивідуальної свободи для своїх громадян [9].

Уряд може реагувати на сецесіонізм кількома способами, деякі з яких $є$ взаємовиключними: погодження на вимоги сепаратистів; поліпшення становища знедолених меншин (релігійних, мовних, територіальних, економічних чи політичних); прийняття "асиметричного федералізму", де різні штати мають різні відносини з центральним урядом в залежності від сецесійних вимог або міркувань; дозволити меншинам брати участь в політичних дискусіях через парламентські голосування, референдуми і т.д.; встановлення конфедерації, в якій існують лише обмежені зв'язки між країнами. Деякі уряди придушують будьякі сепаратистські рухи в їх власній державі, але підтримують прояви сепаратизму в інших країнах.

Країни ЄС $з$ активними сецесійними рухами проводять різну державну політику стосовно них. Розглянемо ії на прикладах таких країн як Іспанії, Бельгії, Великій Британії, Франції та Італії, для яких характерний високий потенціал сецесійного конфрлікту - наявність сецесійних політичних партій та рухів, що мають підтримку місцевого співтовариства і представництво в регіональних органах влади.

Регіональна політика Іспанії зводиться до надання регіонам права на самоуправління і визнання місцевих мов офіційними в автономних областях. Відносини між регіонами та центром побудові на демократичних засадах відповідно до Конституції 1978 року, в якій була закладена ідея збереження сильного центру і створення самоврядних регіонів. Всього зараз в Іспанії 17 автономних утворень і два "заморських" автономних міста Сеута і Мелілья - на півночі Африки. Більшість регіонів стали автономіями в період з 1981 по 1983 р. ( першими цей статус отримали в грудні 1979 Каталонія і Країна Басків). Єдність нації символізує король [8]. І в цьому полягає головний зміст інституту королівської влади в Іспанії, частини якої настільки несхожі одна на одну. За минулі роки стало очевидним, що перерозподіл влади між центром і регіонами, відмова від уніфікації, в принципі, задовольнили основні політичні і громадські сили, окрім украй радикальних.

Хоча в цілому демократизація країни сприяла послабленню сецесіонізму, усе ж автономістські тенденції не зникли. Звідси можна дійти висновку, що навіть ідучи на поступки, надаючи більше автономних прав меншинам, але одночасно, продовжуючи насильницьку боротьбу із сепаратистами, уряд не досягає ефективного врегулювання проблеми і конфлікт залишається нерозв'язаним. В Іспанії, коли один з регіонів домагається більшого обсягу влади, інший прагне того ж, третій - діє аналогічно. При цьому іспанський сепаратизм, на думку Ланглуа, не провокує безпосередньо розпад держави у разі, якщо якийсь із регіонів отримає незалежність, але сецесійні рухи в інших провінціях неминуче ведуть до федералізації держави, адже провінції завжди прагнули до більш широкої автономії [7].

Таким чином, противагою сецесійним прагненням регіонів може служити політика іспанської влади, націлена на реалізацію принципу "багаторівневої ідентичності" (загально іспанської та регіональної), реалізація спільних з автономним регіоном проектів соціально-економічної модернізації, проведення політики розумної децентралізації. Саме завдяки мирним методам врегулювання цих протиріч і конфрліктів (консенсусний підхід), зваженими поступками, задоволенням певних нагальних потреб етнічних меншин, що борються за незалежність, наданням автономних прав і свобод етнічним меншинам у межах Конституції, досягненнями високого рівня в соціально-економічному житті держави як єдиного організму, можна послабити екстремістські й радикальні настрої, зменшити вплив і популярність терористичних організацій, збройних методів боротьби у своїй державі $[7,8]$.

Бельгія реалізувала на практиці модель децентралізованої держави, заснованої на принципах етнічного та лінгвістичного плюралізму. Сучасна Бельгія - це унікальна федерація, що складається із шести суб'єктів двох типів, які накладаються один на одного. По-перше, це екстериторіальні товариства (франкомовне, нідерландомовне й німецькомовне), по-друге, це територіальні регіони (Валлонія, Фландрія й Брюссель - столиця). Кожен із суб'єктів має свої власні законодавчі і виконавчі органи. На даний час у країні діє шість урядів: федеральний, два мовноспільнотних і троє окружних (двоє останніх завідують лише гуманітарними питаннями) [4]. Бельгія відрізняється особливо складною системою державного керування, у якій деталізовані і ураховані вимоги всіх соціальних і етнічних груп.

Двоскладна федерація, що замінила в Бельгії унітарну державу у 1980 році і нова конституція, створили основу для нормальних відносин між фоламандцями та валлонами. Однак, міжетнічний конфлікт так і не був вирішений до кінця. Основними проблемами $є$ статус Брюсселя й столичної периферії, прагнення Фландрії до більшої автономії, а також так звані "мовні війни" (цей термін ввійшов у бельгійський політичний словник через численні конфліктні ситуації, що виникали між франкомовною меншістю й нідерландською більшістю у комунах, що розташовані навколо Брюсселя) [6].

Політичним і суспільним силам країни поки вдається не доводити до крайності протиріччя між валлонами i фламандцями. Цьому сприяють і нечисленні прихильники ідеї відновлення рівноваги компетенцій між центром і суб'єктами. Важливу роль в процесі подолання сецесійних настроїв відіграють бельгійські королі. । франкофони, і валлонофіли не уявляють, як це не мати 
короля, через що він і отримав титул "Короля бельгійців", а не "Короля Бельгії".

Стосовно корсиканського сецесіонізму, то спроби як мирного вирішення конфрлікту шляхом надання Корсиці спеціального самоврядного або автономного регіонального статусу (соціалістичні уряди), так і жорсткі репресивні методи придушення радикального корсиканського націоналізму/сепаратизму з боку правих політичних сил не досягали успіху; головною перешкодою були статті Конституції Франції, згідно яких існує тільки одна "нація" - французька, і, відповідно, тільки одна офіційна мова в усій державі.

Корсиканський сепаратизм в основному вже проявив свій деструктивний потенціал і перетворився в переважно маргінальне політичне явище. Проте ослабити його все ще чималу базу може лише комплексна стратегія фрранцузької держави з реінтеграції острівного департаменту Корсика в єдиний загально французький політичний, правовий та соціокультурний простір [2].

У Великій Британії регіональні проблеми, що склалися історично ще 3 періоду раннього Середньовіччя, Лондон аж до кінця XX століття намагався вирішувати досить жорсткими методами. Для придушення відцентрових тенденцій використовувались економічний тиск, політика переселення англійців на ірландські та шотландські території, а також силові варіанти вирішення конфрліктів з використанням поліції і армії в Північній Ірландії. Це утримувало проблему, на якийсь період зменшувало, але не вирішувало ії.

У 90-х роках XX століття лейбористський уряд Тоні Блера (який за походженням був шотландцем) почав складний процес деволюції - розширення автономії адміністративно-політичних частин королівства. У результаті вперше з 1707 року відновив роботу парламент Шотландії та органів представницької влади у Великобританії стало чотири: головний - в Лондоні і три регіональних - у Шотландії, Уельсі та Північній Ірландії. Вони дозволили різним частинам королівства брати участь в управлінні країною, розширили самоврядування міст. Показником ефективності таких заходів $€$ факт, що 3 1998 р. конфлікти у Північній Ірландії пішли на спад.

Приклад вирішення етнічних проблем у Великобританії $€$ показовим для інших країн Європи та світу. За останні роки уряд зміг реструктуризувати електоральну систему та схему управління регіонами, надавши їм більше свободи в діяльності, прийнятті та виконанні рішень. А результати сучасних перемовин щодо прове- дення референдуму в Шотландії свідчать про те, що перспективи благополучного розв'язання даного сецесійного конфрлікту виглядають значно реальнішими, ніж у Іспанії, де центральна влада жорстко демонструє бажання "приборкати непокірних", не йде на будь-які поступки і вдається до погроз застосування санкцій проти регіональних сепаратистів аж до арештів їхніх лідерів i розпуску регіональних парламентів у разі правових дій, не передбачених конституцією.

В Італії ж розв'язання регіональних проблем ускладнюється не сформованістю міцної, єдиної "загальноіталійської" ідентичності (принаймні, етнокультурної). Основні регіональні відмінності Італії, хоча й складаються з дрібніших місцевих ідентичностей, розташовані на вісі Північ - Південь. Згідно конституційного устрою, Італія $€$ дуже децентралізованою країною, яка, проте, вважається не федеративною, а, скоріше, "поліцентричною" [2]. Італія стала першою країною, що здійснила експеримент з асиметричною децентралізацією. Після Другої Світової війни, запровадження високого рівня регіонального самоврядування було неминучим принаймні на п'яти територіях, з яких найбільш відомими є Трентіно-Південний Тіроль і два південних острова Сицилія та Сардинія. В пошуках "третього шляху" між федеральним та унітарним устроями, була здійснена регіоналізація усієї країни, хоча рівень повноважень решти територіально-адміністративних одиниць нижчий, ніж у зазначених п'яти.Завдяки особливому статусу цих територій проблеми міжетнічних відносин переносяться на другий план. Така політика допомогла знизити міжрегіональну напруженість та змінити сецесійну спрямованість частини рухів на автономістську.

Якщо співвіднести дані про сучасні регіональні конфолікти з формами державного устрою тих країн, в яких вони відмічені, можна побачити, що форма державного устрою від федералізму до унітаризму не є єдиним вирішальним чинником для мінімізації регіональних конфліктів. Тобто перехід держави до федералізму чи надання окремим регіонам статусу автономії не означає автоматичного вирішення проблеми (табл. 1) (під квазіфредераціями розуміємо унітарні держави зі складною структурою адміністративно-територіального устрою і які мають у складі адміністративно-територіальних одиниць автономії чи регіони з особливим статусом, повноваженнями чи власними органами законодавчої, виконавчої і судової влади).

Таблиця 1. Адміністративно-територіальний устрій європейських країн з регіонами потенційної сецесії

\begin{tabular}{|l|l|}
\hline Форма адміністративно-територіального устрою & \multicolumn{1}{|c|}{ Держави } \\
\hline Федерації & Австрія, Бельгія, Німеччина \\
\hline \multirow{2}{*}{ Квазіфредерації } & $\begin{array}{l}\text { Великобританія, Данія, Іспанія, Італія, } \\
\text { Фінляндія, Франція }\end{array}$ \\
\hline \multirow{2}{*}{ Унітарні держави } & Болгарія, Угорщина, Греція, Латвія, Литва, \\
\cline { 2 - 2 } & Нідерланди, Польща, Румунія, Словаччина, Словенія, \\
\cline { 2 - 2 } & Хорватія, Чехія, Швеція, Естонія \\
\hline
\end{tabular}

Регіональні протиріччя і конфлікти $є$ як у федеративних державах (Бельгія, Німеччина), так і в унітарних (Швеція, Греція). Не можна не враховувати історичні, культурні, мовні, економічні чинники. При врахуванні всіх цих фракторів важливо розуміти, що саме політичні механізми можуть стати початковим імпульсом, дати перший поштовх до вирішення протиріч. Тому політичні чинники, хоча і не можуть бути єдиними, але в той же час вони є одними з вирішальних у вирішенні регіональних конфрліктів.

Розглянемо факти успішного вирішення регіональних конфрліктів окремими європейськими державами, а саме
Швейцарією та Німеччиною. Швейцарія складається 3 кантонів, населених носіями трьох провідних мовних груп (німецька, фрранцузька, італійська та ретороманська). Крім фракту визнання цих мов державними (хоча ретороманською говорить лише $1 \%$ населення країни), слід зазначити, що в Швейцарії сильні традиції парламентаризму. До того ж, прийняття рішень у парламенті поєднується 3 практиками регулярного проведення загальних і місцевих ресререндумів серед громадян.

Німеччину можна назвати країною-взірцем регіонального різноманіття. Вся її історія проходила під прапором внутрішніх розломів, воєн і конфліктів. Все це розмаїття 
регіонів було об'єднано у федеральну систему 16 земель. Кожна $з$ них має свій парламент (ландтаг) і виконавчі органи влади, голів яких (прем'єр-міністрів) обирають ландтаги. Також у Німеччині існує практика не тільки політичної, але і географрічної децентралізації верховної влади. Так, Федеральний суд розміщений в Карлсруе, Федеральний адміністративний суд - у Лейпцігу, Федеральний суд з трудових суперечок, федеральний громадський суд і Федеральний фінансовий суд - у Мюнхені. Слід зазначити і те, що німецький федералізм не є способом розв'язання етнічних або мовних проблем. Німеччина - моноетнічна країна, населення якої говорить німецькою мовою. Тим не менше, у ФРН регіональною мовою була визнана нижньосаксонська, а також мови національних меншин, зокрема данська, лужицька та фризька. Федералізм вирішує головне завдання досягнення єдності при збереженні різноманітності [3].

Досвід ефективного вирішення регіональних конфліктів західноєвропейськими державами показав, що у всіх розглянених випадках (Швейцарія, Німеччина) використані механізми інституту парламентаризму і рішення мовного питання. Не менш ефективним може бути впровадження політики географічної децентралізації верховної влади (Німеччина) і легітимації рішень влади через референдуми (Швейцарія)

Висновки. Таким чином, у сучасних умовах процеси інтеграції та регіоналізації відбуваються у більшості європейських країн. Форми регіонального самоуправління повсюдно різняться, але загальна тенденція одна: як тільки починається процес передачі окремих повноважень регіонам, вимоги останніх починають ставати дедалі більш наполегливими і широкими. В Іспанії, де двигуном регіоналізації $є$ Каталонія та Країна Басків, сьогодні вже сформовано інститути так званого "асиметричного федералізму". Децентралізація дійшла і до "бастіону" централізму - Франції, де конгрес ухвалив поправку до Конституції, яка закріпила "децентралізовану організацію" Республіки, і прийняв новий закон про децентралізацію, що представив численні повноваження місцевим органам самоуправління. На сьогоднішній день у половині держав Євросоюзу регіональна влада має законодавчі повноваження і працює як "партнер" $€ \mathrm{C}$.

Водночас, країни ЄС з активними сецесійними рухами здійснюють різну державну політику стосовно них (від надання регіонам права на самоуправління та децентралізації до використання жорстких методів). Однак, головним механізмом у вирішенні регіональних конфліктів у Європі є сам Євросоюз з його принципами регіоналізації, адже зі зниженням функціональної ролі національних урядів сецесіонізм втрачає всякий сенс. Можливе дистанціювання регіону від свого центру, але вихід з держави стає практично недоцільним, оскільки сама держава поступово розчиняється у складі ЄС, що має тенденцію до перетворення з конфедерації держав у велику фредерацію регіонів.

Список використаних джерел

1. Баранов А. В. Сепаратизм в современном мире: Политикотерриториальный аспект // Человек. Сообщество. Управление. - 2005. - № 3. - C. 107-124.

2. Беліцер Н. Регіональна ідентичність і регіональний сепаратизм у сучасній Європі [Електронний ресурс] // Інститут громадянського суспільства. - 2013. - Режим доступу: http://www.csi.org.ual $w w w / ? p=2735$

3. Зоткин А. Механизмы решения региональных конфоликтов в Европейском Союзе: опит для Украины // Наукові записки Інституту політичних і етнонаціональних досліджень ім. І. Ф. Кураса НАН України. - К.,2009. - Вип. 44. (підсерія "Курасівські читання"). - С. 269-280.

4. Ключник Р. Сепаратизм як світова мегатенденція сучасності // Політичний менеджмент. - 2011. - № 6 (51). - С. 120-129.

5. Лажнік В. Й. Невизнані державні утворення як об'єкти сучасної політичної карти світу // Наук. вісн. Волин. нац. ун-ту ім. Лесі Українки. Географічні науки. - 2008. - № 1. - С. 202-211.

6. Мишляєв Т. Ю. "Проблемні місця" бельгійського федералізму // Науковий вісник Волинського національного університету імені Лесі Українки. Географічні науки. - Луцьк, 2008. - № 1. - С. 212-218.

7. Панас Т. О. Еволюція шляхів урегулювання баскського етнополітичного конфлікту в Іспанії // Проблеми міжнародних відносин : зб. наук. праць. - К., 2012. - Вип. 4. - С. 120-127.

8. Фонсека Н. Политика испанского государства по противнодействию сепаратизму // Вестник Томского государственного университета. - 2012. - № 3 (19). - C. 128-133.

9. Lustick I. Secessionism in multicultural states: does sharing power prevent or encourage it? // American Political Science Review. - 2004. Vol.98, no.2 - P. 209-229.

Надійшла до редколегії 24.09.16

Л. Ковалевич, асп.

Киевский национальный университет имени Тараса Шевченко, Киев, Украина

\section{ПОЛИТИКА ГОСУДАРСТВ ЕВРОПЕЙСКОГО СОЮЗА ПО ПРОТИВОДЕЙСТВИЮ СЕЦЕССИОНИЗМУ}

В статье рассмотрена роль внутренней политики государства в решении межрегиональных противоречий и противодействия сецессионным процессам. Освещены основные способы реагирования правительства на усиление центробежных тенденций в отдельных регионах. Проанализированы главные характерные черты государственной политики стран Европейского Союза, в которых имеются регионы с высоким потенциалом сецессионного конфликта. Подчеркнута необходимость взвешенной внутренней политики правительства для предотвращения эскалации внутригосударственных противоречий. Исследовано влияние формы государственного устройства на минимизацию межрегиональных противоречий. Рассмотрены примеры успешного решения региональных конфликтов отдельными европейскими государствами.

Ключевые слова: сецессионизм, Евросоюз, государственная политика, сецессионные движения, межрегиональные конфликты.

L. Kovalevych, postgraduate student

Taras Shevchenko National University of Kyiv, Kyiv, Ukraine

\section{POLICY OF THE STATES OF THE EUROPEAN UNION AGAINST SESSESIONISM}

The role of domestic policy in solving of inter-regional conflicts and counteracting secessionist processes are disclosed in the article. A mixed population in any area can live either in peaceful coexistence and political stability or in violent conflicts. This is mostly dependent on the internal ethnic policy. Variety of the government's reactions to the strengthening of centrifugal tendencies in some regions are explored; among which the approval of separatist demands, the advancement of conditions of underprivileged minorities, adoption of "asymmetric federalism", allowance for minorities to participate in political debate through parliamentary voting, referendums, etc., establishment of a confederation with only limited links between countries are distinguished. Another way to solve regional conflicts is to create a "multinational federation." The main features of the state policy of the European Union's countries which have regions with high potential secessionist conflict are analyzed. The necessities of a balanced domestic policy of the government to prevent the escalation of internal contradictions are emphasized. The influence of the form of government on minimizing of inter-regional conflicts is investigating. After correlating data about current regional conflicts and the forms of government of the hosting countries, it was found that the form of government (from unitary to federalism) is not the only decisive factor for solving of regional conflicts. However, taking into account the historical, cultural, linguistic, economic factors, it is important to understand that political mechanisms can give an initial impulse, the first impetus to resolve the conflicts. Therefore, political factors are some of the key one in regularizing of secessionism. Moreover, examples of the successful resolution of regional conflicts by particular European states are considered. Experience of an effective resolving of regional conflicts in western European countries showed that in all the cases (Switzerland, Germany, Spain and Great Britain) the mechanisms of $i$ the institution of parliamentarism and solving of the language issue were used. The geographic decentralization policy of the supreme power (Germany) and legitimization of government decisions through referendums (Switzerland) are equally effective.

Keywords: secessionism, the European Union, public policy, secessionist movements, inter-regional conflicts. 